\title{
A Novel Test System for Genotyping rs43703016 Single-nucleotide Substitutions in the Bovine CSN3 Gene
}

\author{
Svetlana Kovalchuk ${ }^{1}$, Arina Tagmazyan ${ }^{1}$ and Eugene Klimov ${ }^{1,2^{*}}$ \\ ${ }^{1}$ Center of Experimental Embryology and Reproductive Biotechnologies, Moscow, \\ Russian Federation. \\ ${ }^{2}$ Lomonosov Moscow State University, Faculty of Biology, Moscow, Russian Federation.
}

\begin{abstract}
Authors' contributions
This work was carried out in collaboration among all authors. Author SK designed the study, wrote protocols and wrote the draft of the manuscript. Author AT performed the experiments and wrote the first draft of the manuscript. Author EK managed the literature searches and wrote the final manuscript. All authors read and approved the final manuscript.
\end{abstract}

Article Information

DOI: 10.9734/ARRB/2019/v32i430090 Editor(s):

(1) Dr. Jean-Marie Exbrayat, Professor, Universite Catholique de Lyon, France.

Reviewers:

(1) Haifa El-Hentati, Permanent University, USA. (2) Grace O. Tona, University of Technology, Nigeria. (3) Marco Antonio Santillan Flores, Instituto Nacional de Investigaciones Forestales, Mexico. (4) Oluwole Olufunke, Obafemi Awolowo University, Nigeria. Complete Peer review History: http://www.sdiarticle3.com/review-history/50257

Method Article

Received 14 May 2019

Accepted 24 July 2019

Published 30 July 2019

\section{ABSTRACT}

Aims: Caseins are among the main milk proteins that determine many of its properties. Bovine kappa-casein (CSN3) is associated with the qualitative composition of milk, as well as with the quality of cheese obtained from this milk. The rs43703016 single-nucleotide substitution (g.88532332A>C; Asp148Ala) in exon 4 of the bovine CSN3 gene plays an important role in the production of quality hard cheeses. Various methods for the DNA testing of this substitution have been developed in the last three decades. Emergent DNA technologies provide an opportunity to modernize methods of genotyping single-nucleotide polymorphisms.

Results: We have developed and verified a method to differentiate A/C alleles of the rs 43703016 substitution in the bovine CSN3 gene by real-time PCR using allele-specific fluorescent probes.

Conclusion: Our new method allows fast genotyping of animals, and may be used for selection of cows carrying the CC genotype, which determines good cheese-making properties of milk. 
Keywords: Cattle; CSN3 gene; rs43703016 single-nucleotide; genotyping; real-time PCR.

\section{INTRODUCTION}

Marker-assisted selection in animal breeding is based on genotype knowledge and selection of animals with genetic data that are best from the industrial point of view. In this respect, particular attention has been paid to milk proteins, in particular caseins [1]. The CSN3 gene encoding kappa-casein has been receiving the most attention. Several substitutions in this gene have been identified and described [2]; and 3 of them affect the characteristics of milk: rs43703015 [3], rs43703016 [4,5] and rs43703017 [3]. From a practical point of view, the rs43703016 substitution (g.88532332A>C; Asp148Ala) is of particular interest. It should be mentioned that the alleles of this polymorphism were denoted in the literature with the letters $A$ and $B$ (nucleotides $A$ and $C$, respectively) until recently. The kappacasein complex haplotypes, 136Thr(A)/lle(B) and 148Asp $(A) / A l a(B)$, are also called alleles $A$ and $B$ [6].

This substitution stirred an interest long ago, when the alleles were shown to affect the content of milk proteins and the quality of cheese [7-10], and this interest is still displayed [3, 11-16]. The $\mathrm{C}$ allele of this polymorphism is industrially valuable.

The first DNA test systems for allele testing of this substitution first appeared approximately 30 years ago [17]. Novel test systems emerged with the modernization of PCR technology and development of new methodological approaches; they use amplification of fragments of several genes and hybridization with variant-specific probes [patent WO2007107862A2, 2007], tetraprimer PCR [patent RU2386700C1, 2010], amplification and polymorphism assessment based on the melting temperature of PCR products of the CSN3 and LGB genes [patent CZ303083B6, 2012], allele-specific PCR [patent RU2013106990A, 2014], and real-time PCR for allele testing of 3 substitutions in the gene at the same time [patent RU2646140C1, 2018]. The latter test system is the most effective one; however, it does not allow assessment of the cistrans positions of the substitutions in question. As can be concluded, the interest in the development of methods that can be used for allele testing of the rs43703016 substitution in the CSN3 gene is not waning. A simple, fast, and inexpensive method for mass genotyping for this polymorphism in cattle is needed.
The objective of the reported study was to develop and verify a method to differentiate $A / C$ alleles of the rs43703016 substitution in the bovine CSN3 gene by real-time PCR (RT-PCR).

\section{MATERIALS AND METHODS}

The study was conducted on 94 samples obtained from black-and-white Holsteinized cows of the Pravda-N LLC animal farm (Dzerzhinsk District, Kaluga Region).

\subsection{DNA Isolation and Oligonucleotide Design}

DNA was isolated from 94 whole blood samples obtained from black-and-white Holsteinized cattle using an M-sorb kit (Sintol, Russia).

The nucleotide sequences of the primers and probes were selected with the help of the GeneRunner and Multiple primer analyzer software (https://www.thermofisher.com/). The primers and probes were synthesized by DNAsynthesis LLC (Moscow, Russia).

\subsection{Real-time PCR}

The amplification reaction was performed in 10 $\mu \mathrm{L}$ of a PCR mixture containing $5 \mu \mathrm{L}$ of the LightCycler ${ }^{\circledR} 480$ Probes Master reagent (Roche, Switzerland), a mixture of the straight primer k-casein-F: 5'-CCATCGAAGCAGTAGA GAGCA-3' and the reverse primer k-casein-R: 5'GGACTGTGTTGATCTCAGGTGG-3' (10 $\mu \mathrm{M})$, $0.4 \mu \mathrm{M}$ of each of the allele-specific probes, kcasein-C: 5'-FAM-CTACTCTAGAAGCTTCTCC AG-BHQ1-3' and k-casein-A: 5'-VIC-CTACTCTA GAAGATTCTCCA-BHQ1-3', and $10 \mathrm{ng}$ of the DNA. PCR was carried out using a LightCycler 96 device (Roche, Switzerland) under optimized conditions (initial denaturation at $95^{\circ} \mathrm{C}$ for 10 min followed by 40 cycles of amplification: $95^{\circ} \mathrm{C}$ for $20 \mathrm{~s}, 55^{\circ} \mathrm{C}$ for $30 \mathrm{~s}, 72^{\circ} \mathrm{C}$ for $20 \mathrm{~s}$ ). Fluorescence was detected at the elongation stage in the FAM and VIC channels. Results were analyzed with the LightCycler® 96 version SW1.1 amplifier software (Roche, Switzerland).

\subsection{Method Validation}

Validation was performed with PCR-RFLP. The PCR utilized $0.2 \mu \mathrm{M}$ portions of the primers $\mathrm{k}$ cas-D: 5'-ATAGCCAAATATATCCCAATTCAG-3' and k-cas-R: 5'-TTTATTAATAAGTCCATGAA 
TCTT-3', Fusion Hot Start II High-Fidelity DNA polymerase kit (Thermo Scientific, USA), used in accordance with the manufacturer's instructions and $30 \mathrm{ng}$ of the genomic DNA. The PCR was performed using a T100 amplifier (Bio-Rad, USA) under the following conditions: pre-denaturation at $98^{\circ} \mathrm{C}$ for $30 \mathrm{~s}, 40$ amplification cycles at $-98^{\circ} \mathrm{C}$ - $10 \mathrm{~s}$, at $55^{\circ} \mathrm{C}-30 \mathrm{~s}$, at $72^{\circ} \mathrm{C}-1 \mathrm{~min}$. The restriction was performed in $20 \mu \mathrm{L}$ of a mixture containing $2 \mu \mathrm{L}$ of a $10 \mathrm{x}$ buffer and 1 unit of Hind III endonuclease (Thermo Scientific, USA); obtained amplicons were processed for 16 hours at $37^{\circ} \mathrm{C}$. The restriction results were assessed using electrophoresis in $1.2 \%$ agarose gel.

The occurrence rates of identified genotypes were calculated by direct counting.

\section{RESULTS AND DISCUSSION}

In this study, we developed a new test system for genotyping rs43703016 single-nucleotide substitutions in exon 4 of the kappa-casein gene (CSN3) using real-time PCR with allele-specific fluorescent probes.

The developed test system utilized two primers common to both alleles of the CSN3 gene and two allele-specific TaqMan probes labeled with FAM and VIC reporter dyes. The k-cas-D and kcas-R primers are used to amplify an $85 \mathrm{bp}$ fragment of the CSN3 gene. Identification of alleles $C$ and $A$ of the rs 43703016 substitution in the CSN3 gene is based on comparison of the

fluorescence intensities of the FAM and VIC reporter dyes, respectively. The genotyping analysis was carried out using the LightCycler ${ }^{\circledR}$ 96 version SW1.1. amplifier software (Fig. 1).

CC cows were found to have an increase in fluorescence signal in the FAM channel (Fig. 1A). In AA cattle, the fluorescence signal was registered in the VIC channel (Fig. 1C). Heterozygous cows (genotype AC) had signal detected in both channels, FAM and VIC (Fig. 1B). Therefore, RT-PCR results obtained with allele-specific TaqMan probes allow detection of the presence in the analyzed DNA sample of each of the studied alleles ( $C$ and $A$ ) of the rs43703016 substitution in the CSN3 gene and, accordingly, determination of the animal's genotype.

The proposed real-time PCR-based test system was validated on 94 DNA samples obtained from black-and-white Holsteinized cattle. The genotyping results revealed that $49 \%$ of the animals were carriers of both alleles (genotype $\mathrm{CA}), \quad 38 \%$ of the cows were allele $A$ homozygotes (genotype AA), and $13 \%$ of the cattle were allele $C$ homozygotes (genotype $C C$ ). These results are generally consistent with available literature data on the frequencies of these genotypes in cattle populations (e.g., [6]) or information from ENSEMBL genome database: AC $37.5 \%$; AA $50.0 \%$; CC $12.5 \%$ [https://www.ensembl.org/].
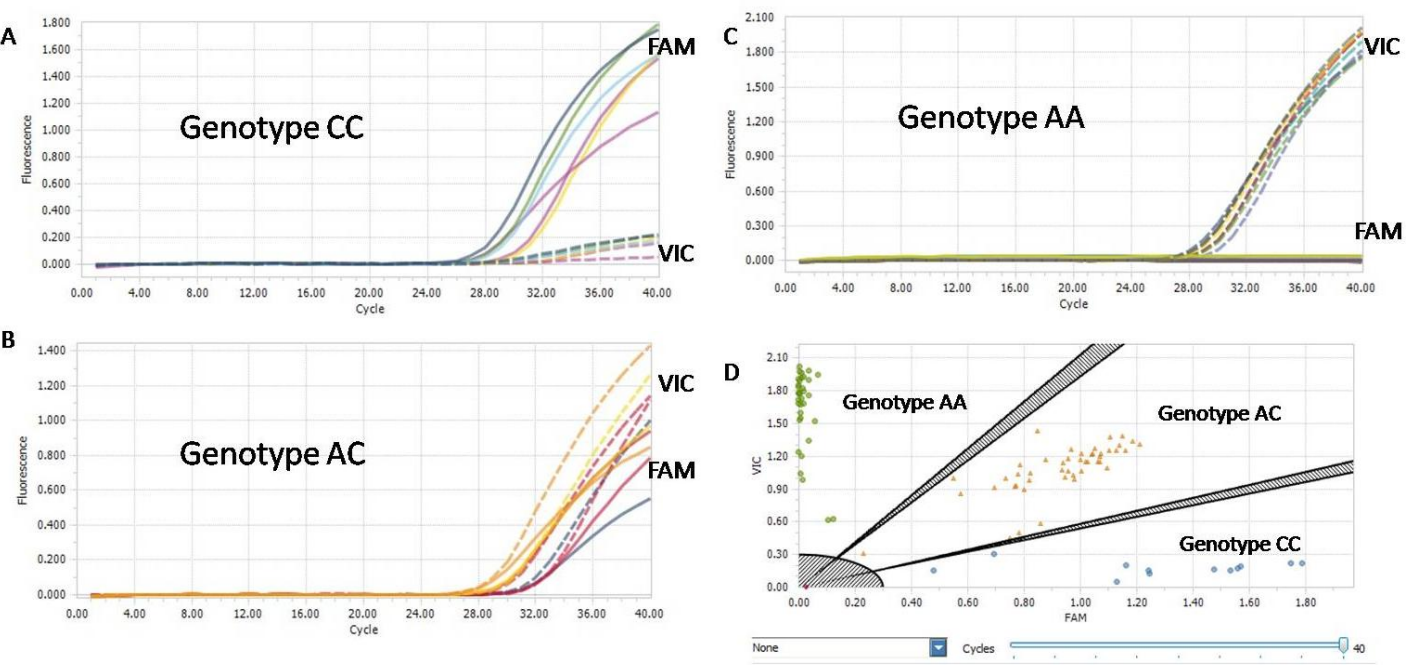

Fig. 1. Example of the detection of allele variants $C$ and $A$ of the rs 43703016 substitution in the bovine CSN3 gene by real-time PCR. Fluorescence curves (A-C) and the genotype distribution (D) are presented 


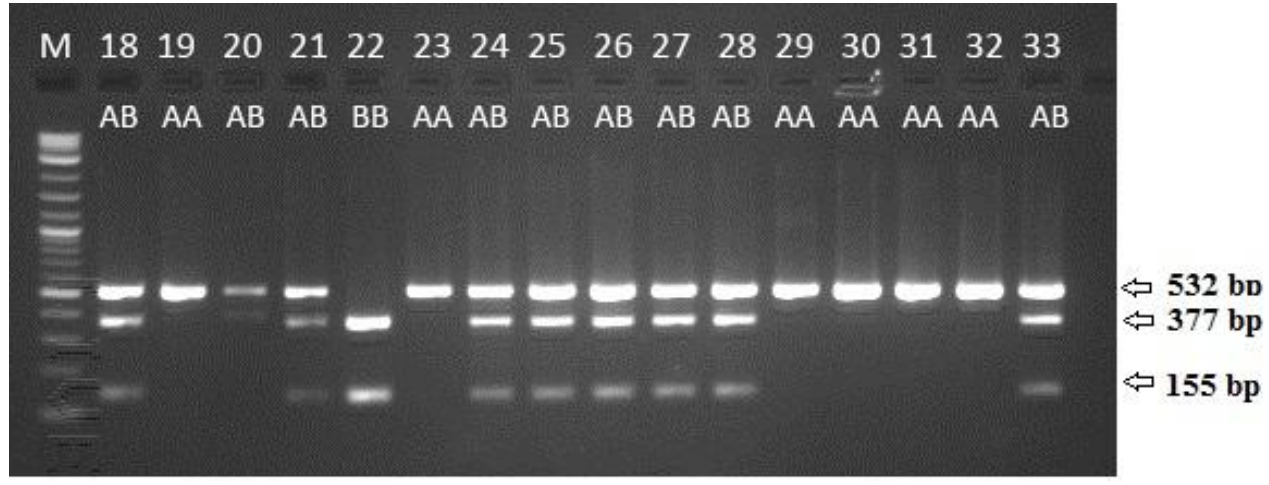

Fig. 2. An example of cattle genotyping results with regard to alleles $A / C$ of the rs 43703016 substitution in the CSN3 gene

The proposed method was validated using PCRRFLP analysis [18]. Results obtained with the two genotyping methods completely coincided; however, the method proposed in this paper allows significant (up to 1 hour) reduction of the assay time, which gives it an advantage over PCR-RFLP analysis. Additionally, the use of RTPCR allows to avoid an electrophoresis stage and, consequently, contamination of the laboratory with amplification products of the CSN3 gene fragment.

\section{CONCLUSION}

Thus, we have developed an effective and reliable test system for detection of the C/A polymorphism in the bovine kappa-casein CSN3 gene (rs43703016) by real-time PCR using allele-specific Taq Man fluorescent probes. This method allows genotyping of up to 480 animals (depending on the amplifier model) within 1 hour, and may be used for selection of cows carrying the CC (or BB) genotype, which determines good cheese-making properties of milk.

\section{ETHICAL APPROVAL}

As per international standard ethical approval has been collected and preserved by the authors.

\section{COMPETING INTERESTS}

Authors have declared that no competing interests exist.

\section{REFERENCES}

1. Shevtsova AA, Klimov EA, Kovalchuk SN. Review of genes variability associated with milk productivity of dairy cattle. International Journal of Applied and Fundamental Research. 2018;11:194-200. Russian.

DOI:10.17513/mjpfi.12475

2. Patel JB, Chauhan JB. Computational analysis of non-synonymous single nucleotide polymorphism in the bovine cattle kappa-casein (CSN3) gene. Meta Gene. 2018;15:1-9.

DOI:10.1016/j.mgene.2017.10.002

3. Viale E, Tiezzi $F$, Maretto $F$, et al. Association of candidate gene polymorphisms with milk technological traits, yield, composition, and somatic cell score in Italian Holstein-Friesian sires. J Dairy Sci. 2017;100:7271-7281.

DOI:10.3168/jds.2017-12666

4. Wang Q, Bovenhuis H. Genome-wide association study for milk infrared wavenumbers. J Dairy Sci. 2018;101: 2260-2272.

DOI:10.3168/jds.2017-13457

5. Alim MA, Dong $T$, Xie $Y$, et al. Effect of polymorphisms in the CSN3 (K-casein) gene on milk production traits in Chinese Holstein Cattle. Mol Biol Rep. 2014; 41:7585-7593.

DOI:10.1007/s11033-014-3648-x

6. Sulimova GE, Azari MA, Rostamzadeh J, et al. k-casein gene (CSN3) allelic polymorphism in Russian cattle breeds and its information value as a genetic marker. Russian Journal of Genetics. 2007;43:73-79.

DOI:10.1134/S1022795407010115

7. Schaar J, Hansson B, Pettersson HE. Effects of genetic variants of $\mathrm{K}$-casein and $\beta$-lactoglobulin on cheesemaking. Journal of Dairy Research. 1985;52:429-437. 
DOI:10.1017/S002202990002433X

8. Schaar J. Effects of K-casein genetic variants and lactation number on the renneting properties of individual milks. Journal of Dairy Research. 1984;51:397406.

DOI:10.1017/S0022029900023694

9. Robitaille G. Influence of $\mathrm{K}$-casein and $\beta$ lactoglobulin genetic variants on the heat stability of milk. Journal of Dairy Research. 1995;62:593-600.

DOI:10.1017/S0022029900031320

10. Zadworny D, Kuhnlein U. The identification of the kappa-casein genotype in Holstein dairy cattle using the polymerase chain reaction. Theoretical and Applied Genetics. 1990;80:631-634.

DOI:10.1007/BF00224222

11. Smiltina D, Grislis Z. Molecular genetics analysis of milk protein gene polymorphism of dairy cows and breeding bulls in Latvia. Agronomy Research. 2018;16(3):900-909.

DOI:10.15159/ar.18.084

12. Huang W, Peñagaricano F, Ahmad KR, et al. Association between milk protein gene variants and protein composition traits in dairy cattle. Journal of Dairy Science. 2012;95:440-449.

DOI:10.3168/jds.2011-4757

13. Zhihua Ju. The polymorphisms of $\mathrm{k}$-casein gene and their associations with milk production traits and expression analysis in
Chinese Holstein cattle. African Journal of Biotechnology. 2011;10(62):13368-13375. DOI:10.5897/AJB10.1886

14. Ahmed AS, Rahmatalla S, Bortfeldt R, et al. Milk protein polymorphisms and casein haplotypes in Butana cattle. Journal of Applied Genetics. 2017;58:261-271.

DOI:10.1007/s13353-016-0381-2

15. Cecchinato A, Ribeca C, Chessa S, et al. Candidate gene association analysis for milk yield, composition, urea nitrogen and somatic cell scores in Brown Swiss cows. Animal. 2014;8:1062-1070.

DOI:10.1017/S1751731114001098

16. Kyselová J, Ječmínková K, Matějíčková J, et al. Physiochemical characteristics and fermentation ability of milk from Czech Fleckvieh cows are related to genetic polymorphisms of $\beta$-casein, $\mathrm{k}$-casein, and $\beta$-lactoglobulin. Asian-australas J Anim Sci. 2019;32:14-22.

DOI:10.5713/ajas.17.0924

17. Sulimova GE, Shaikhaev GO, Berberov $\mathrm{EM}$, et al. Genotyping the bovine kappacasein locus using polymerase chain reaction. Genetika. 1991;27:2053-2062. Russian.

18. Sulimova GE, Sokolova SS, Semikozova $\mathrm{OP}$, et al. Analysis of DNA polymorphism of cluster genes in cattle: casein genes and major histocompatibility complex (MHC) genes. Tsitol Genet. 1992;26:1826. Russian.

(c) 2019 Kovalchuk et al.; This is an Open Access article distributed under the terms of the Creative Commons Attribution License (http://creativecommons.org/licenses/by/4.0), which permits unrestricted use, distribution, and reproduction in any medium, provided the original work is properly cited.

Peer-review history:

The peer review history for this paper can be accessed here: http://www.sdiarticle3.com/review-history/50257 